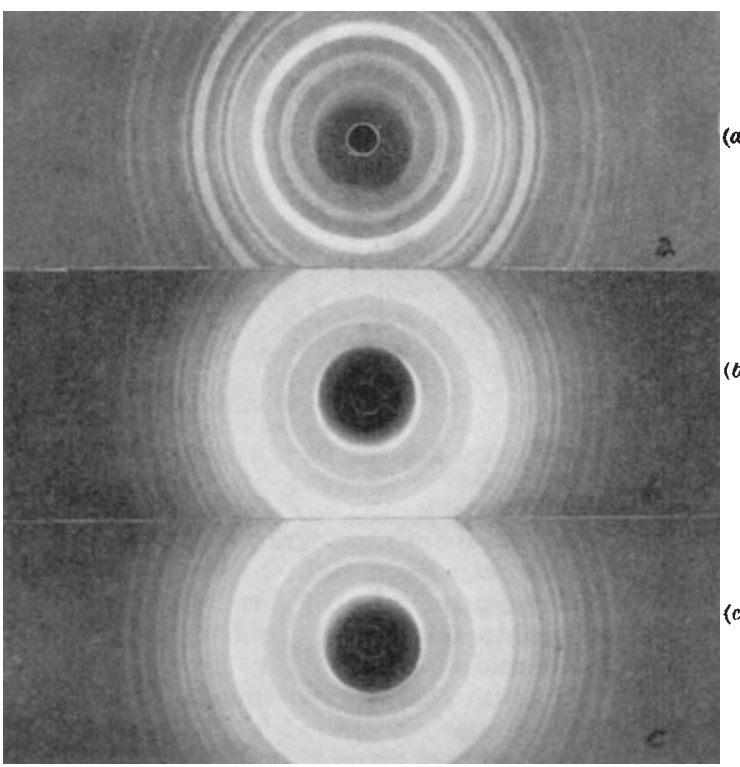

Fig. 3. X-ray diffraction patterns of $(a)$ ' $T$-spot'; $(b)$ synthetic $B$-aminoisobutyric acid ; $(c)$ racemized ' $T$ 'spot'

tion of the ' $T$-spot' from the creatinine was then brought about by a further fractionation on the anion-exchange resin 'Dowex 2 '5. On evaporation of the selected fractions, a crop of hygroscopic white crystalline material was obtained of melting point 183-184 (all m.p.'s uncorrected) ; C, 46.0 ; H, 8.4 ; $\mathrm{N}, 13 \cdot 6$ per cent; calculated for $\mathrm{C}_{4} \mathrm{H}_{9} \mathrm{O}_{2} \mathrm{~N}: \mathrm{C}, 46 \cdot 6$; $H, 8 \cdot 7$; N, $13 \cdot 6$ per cent. The yield was about 300 mgm. from 3 litres of urine.

From the accumulated evidence of chemical properties, paper chromatography, elementary analysis, ion-exchange column behaviour and a microtitration curve, it appeared certain that ' $T$-spot' must be a mono-amino-monocarboxylic compound with four carbon atoms. All but one of the eight possible isomers could be eliminated from their known chemical properties and from their known behaviour on paper chromatograms. The only remaining possibility was $\beta$-aminoisobutyric acid. This substance was synthesized by Pollack ${ }^{8}$, who records its melting point as $180^{\circ}$. Its chromatographic behaviour when run on filter paper with butanol/acetic acid has also been reported ${ }^{7}$. We have been fortunate enough to obtain a small sample of this original preparation. The synthetic material and our ' $T$-spot' behaved identically on paper chromatograms run with phenolammonia, collidine-lutidine and butanol-acetic acid. The synthetic substance also resembled ' $T$-spot' in that it failed to form a copper complex under our usual conditions. On the other hand, the melting point of our isolated material was $183-184^{\circ}$, and a mixed melting point gave $174-175^{\circ}$. Moreover, the X-ray diffraction patterns were different (Fig. 3). Since our isolated ' $T$ 'spot' was lævorotatory (in water), it was probable that these differences were due to the optical configuration of the two samples. We could not attempt a resolution of the small quantity of synthetic material, so we endeavoured to racemize $30 \mathrm{mgm}$. of the isolated ' $T$-spot' by alkaline hydrolysis (5N NaOH/16 br. $/ 105^{\circ}$ in a sealed tube). It was recovered by the cation-exchange procedure in a pure condition and with its chromatographic properties unchanged The melting point was now lowered to $177^{\circ}$ and a mixed melting point with the synthetic substance also gave $177^{\circ}$. Moreover, the $X$-ray diffraction patterns of the two substances were now identical (Fig. 3).

We therefore have no doubt as to the identity of this newly found amino-acid. We are not aware of any report so far of the existence of such a curious molecule in Nature (Fig. 4). We cannot resist pointing out here, however, that if ammonia is removed from $\beta$-aminoisobutyric acid, the product is methacrylic acid. If, therefore, the ammonia loss occurs as readily in vivo as it does in vitro (by heating), then there are obvious synthetic potentialities in the new amino-acid. Work is proceeding on the isolation of larger quantities, and on its properties and significance. We hope to report the final resuits more fully elsewhere.<smiles>CC(CN)C(=O)O</smiles>

Fig. 4

We gratefully acknowledge the valuable help of Mrs. Kennard, who carried out the X-ray diffraction studies, the generosity of Dr. L. J. Reed, who gave us a sample of synthetic $\beta$-aminoisobutyric acid, and the Dow Chemical Company for their gift of a sample of 'Dowex 2'. One of us (H. H.) is in receipt of a grant from the Medical Research Council.

[Oct. 16 .

${ }^{2}$ Dent, C. E., Biochem. J., 43, 169 (1948).

2 Crumpler, H. R., and Dent, C. E., Nature, 164, 441 (1949).

${ }^{3}$ Partridge, S. M., and Westall, R. G., Biochem. J., 44, 418 (1949).

${ }^{4}$ Westall, R. G., J. Soc. Food and Agric., 1, 191 (1950).

${ }^{5}$ Partridge, S. M., and Brimley, R. C., Biochem. J. (in the press).

Pollack, M., J. Amer. Chem. Soc., 65, 1335 (1943)

' Reed, L. J., J. Biol. Chem., 183, 451 (1950).

\section{THE NATIONAL METALLURGICAL LABORATORY OF INDIA}

$T$

HE National Metallurgical Laboratory of India, declared open by Mr. Jawaharlal Nehru, Prime Minister of India, at Jamshedpur on November 26, 1950 , is the sixth to be formally launched in the series of eleven national laboratories being set up by the Council of Scientific and Industrial Research; an outline of the plans for the Laboratory appeared in Nature of February 15, 1947, p. 219. That such an institution was much needed to ensure the development of India's metallurgical industries was the conclusion reached by a Metals Research Committee set up a decade ago by the Board of Scientific and Industrial Research. The next decision was about its location at Jamshedpur, the "Steel City" where the Tata steel works are situated. A Planning Committee was set up in 1943 with Sir J. J. Ghandy, director in charge of the Tata Steel Works, as chairman. Funds were to be available in the post-war years. Mr. C. Rajagopalachari, then Education Minister in the Interim National Government, laid the foundation stone of the Laboratory towards the end of 1946. Construction started in 1948, and in the following year the Laboratory began to function in the uncompleted building.

The inauguration was an impressive ceremony. Mr. J. R. D. Tata presided. The Governor of West 
Bengal, Mr. Jawaharlal Nehru, who then held the portfolio of scientific research, three other Cabinet Ministers -the Minister for Transport, the Minister for Works, Mines and Power, and the Minister for Industries and Supply (who also serves as vicepresident of the Council of Scientific and Industrial Research, the parent body of the National Laboratories), Sir Shanti Swarup Bhatnagar, secretary of the Department of Scientific Research and director of the Council of Scientific and Industrial Research, and a number of men of science and industrialists were among those present.

Mr. J. R. D. Tata, in welcoming the distinguished guests, spoke of the "competitive race" among metals; he remarked that while iron and steel continue to dominate, aluminium has already come into its own, and is now being crowded out of certain fields by magnesium. Mr. Tata spoke of titanium as a new formidable competitor on the metallurgical horizon. "Fortunately for us," he concluded, "India is blessed with an abundant supply of all the more important metallic ores, although it is short of less essential non-ferrous metals." $\mathrm{He}$ expressed the confident hope that the new Laboratory "will make a powerful contribution to the technological and industrial advancement of our country".

Sir J. J. Ghandy, as chairman of the Planning Committee, gave a brief history of the project and explained the purposes that the Laboratory would be expected to serve, paying a warm tribute to Sir Shanti Bhatnagar, who, he said, could be fitly compared to that beryllium-copper alloy commonly known as the 'tireless alloy'.

Emphasizing the need for metallurgical research in India, Sir Shanti Bhatnagar in his address said that "in spite of the great strides which Indian industry has made and the fact that the steel works at Jamshedpur constitute the largest single steel unit in the British Commonwealth, we are short of iron by about a million tons a year". He then directed attention to the importance of ilmenite and to the growing trend to divert it from its use in the form of titanium dioxide in paints to its conversion into virgin metal, titanium, for structural purposes. India's reserves in titanium are very large-the ilmenite deposits are estimated at about 300 million tons - and Indian ilmenite, besides, is easily accessible and of a considerably richer grade than that being processed in Brazil, Australia or Canada.

Referring to metals which have lately attracted special attention because of work on atomic energy, Sir Shanti observed that India has the largest deposits of thorium in the world, and that uranium has been located in two different tracts in India, where geological exploration is already in progress. Preliminary results from this hold out promise of "extensive areas rich in uranium". Work on the metallurgy of beryllium has lately made good progress and a geological survey for beryl has been completed. Sir Shanti referred to the experiments at Los Alamos which had given unprecedented importance to lithium, and observed that India, wedded to non-violence, is one of the few countries possessing good quantities of this rare metal needed for super bombs.

Referring to the work already done in the Jamshedpur Laboratory, Sir Shanti claimed that it has established that it is possible to control an austenitic grain size of steel by judicious use of very small quantities of aluminium as an alloying element.
Such grain-refined steels of superior properties have been produced in the laboratory, and now it is for industry to put to use the processes perfected there. $\mathrm{He}$ also mentioned that, with an electrolytic cell designed in the Laboratory, it has been found possible to prepare the highly polished surfaces so often required as mirrors or reflectors in many scientific instruments.

Prof. Charles Crussard, who has taken charge of the Laboratory as its director, paid a tribute to the Council of Scientific and Industrial Research for its ambitious research planning, and remarked that India is one of the few countries to build a national metallurgical laboratory. $\mathrm{He}$ found the laboratory as a self-contained unit to be "just the right size", and did not appreciate the pessimism of those who thought that the economy cuts had adversely affected the project. He found great similarity in the Jamshedpur Laboratory and its opposite number in Francethe Central Research Institute being built by the French Corporation of the Iron and Steel Industry.

Dr. H. Contractor, assistant director of planning, under whom the Laboratory functioned hitherto, thanked all those whose co-operation had enabled him to complete his task.

Mr. Jawaharlal Nehru declared open the Laboratory "in a spirit of hope and in a spirit of faith in the future". In his address he emphasized the need for "giving science a free hand to grow unattached and not tied to any particular problem". At the same time, he observed, the marriage of science and industry is important "because that means that we utilize science to the immediate advantage of, the betterment of, our people". These hundreds of millions, he said, count-c"and nobody else counts in the ultimate analysis". "If anything that we do does not directly or indirectly, if you like, affect their lives and homes, and what they live for and what they hope for, then for the moment that is no progress, although ultimately it may lead to progress." So he was happy over the combination of the new laboratory with Jamshedpur's renowned steel worksover "the marriage of science with industry for the progress of both".

The new Laboratory owes a great deal to Tata munificence. They provided the site-18 acres for the laboratories and another 18 for staff quartersbesides a donation of nearly Rs. 12 lakhs from the Ratan Tata Trust. (The Government of India has given Rs. 38 lakhs.) The Laboratory consists of a main building containing administrative conference rooms, research laboratories, dark rooms, studio, stores, library, reading room, refectory, etc., and a separate technological laboratory comprising five large bays with associated control rooms, and a sub-station housing two 500-kVA. transformers. The main building of the Laboratory is a three-storied structure with a floor area of about $50,000 \mathrm{sq}$. ft. Fume-producing laboratories have been kept in the east of the building, while the physical and metallurgical sections housing delicate instruments occupy the west portion. $X$-ray laboratories on the first floor have also been kept at an extremity. For the present, only the first floor, part of the ground floor and the conference rooms on the second floor are being air-conditioned.

To the south of the main building lies the technological laboratory-named after Sir Ratan Tata in appreciation of the donation received from the Ratan Tata Trust-covering about 38,000 sq. ft. This laboratory will house machine shop, pattern shop, 
instrument making, experimental foundry, foundry testing laboratory, electrical repair shop, melting and heat-treatment furnaces, mechanical working equipment such as rolling mill, hammer, draw-bench, etc., refractories, laboratories with associated furnaces, ore-dressing and mineral benefication laboratories, crushing room, etc. Some of the heavier machinery and pilot plant as originally envisaged have not for the present been ordered; but when funds are available these will be mounted in the bays awaiting them.

After the Laboratory had been declared open, the guests went on a tour of inspection. An interesting exhibit which was placed not in the museum but installed in the foreground, and which attracted special notice, was a full-sized copy of the 2,200-year-old Asoka Pillar at Benares. The capital of this Pillar has been adopted by republican India as its crest and its symbol. The Jamshedpur pillar bears the following legend: "This replica of the Asoka Pillar cast for the workers of the National Metallurgical Laboratory of India, was installed on the 26th November, 1950, on the opening of the Laboratory by Jawaharlal Nehru, Prime Minister of India, as a symbol of the science and industry of India in the past, a token of the present and an inspiration for the future".

Another interesting exhibit was a reproduction of the famous iron pillar of Delhi.

\section{NATIONAL INSTITUTE FOR RE- SEARCH IN DAIRYING, SHINFIELD REPORT FOR 1949}

$\mathrm{W}$ E were recently reminded in a lecture to the Royal Society that the National Institute for Research in Dairying began, in 1912, with a staff of two men and a boy, with an annual income of $£ 1,600$ and with its accommodation in the two extremes of discomfort-an attic and a cellar. This report for 1949* shows, in its first pages, a staff of about seventy scientifically qualified people with a similar number of technical assistants, and, in addition, considerable administrative and maintenance staffs. There are seven scientific departments, a statistics section, a library and an experimental dairy, and the Institute has its own farms and dairy herd. There is also a laboratory for cod liver oil standardization, and associated with the Institute are the Commonwealth Bureau of Dairy Science and the Reading Cattle Breeding Centre. The last pages of the report, dealing with membership, subscriptions and donations, indicate that further expansion is envisaged, and this is not surprising considering the size of the dairying industry and the amount of its turnover.

The dairy husbandry section manages the farms and is faced with the inevitable difficulties (enhanced by a self-contained herd) of combining farm management with the provision of research fucilities and the demand for advisory work. The department has, in addition, its own investigations.

A brief article cannot attempt to describe all the work. Moreover, although the report is presented under departmental headings, the subjects referred to here are not credited to particular departments since so much of the work necessarly involves

* University of Reading: National Institute for Research in Dairying. Report for the year 1949. Pp. 80. (Reading: National Institute for Research in Dairying, Shinfleld, 1950.) collaboration between departments and between the Institute and other bodies. This article will only try to show and exemplify the scope of the work of the Institute.

Dealing with food itself, the value of certain fodder crops (kale, maize for silage and fodder beet) for dairy stock continues to $b_{\theta}$ investigated; but not all the results have yet been statistically analysed. The demonstration in 1948 of cestrogen in British pasture is being followed by the study of œstrogenic activity in certain grasses and clovers and of its practical significance, a matter on which little or nothing is known at present.

Experiments on the rate of passage of food through the animal show that the lesser digestion of crude fibre in ground hay (compared with that of unground hay) is not due to differences of rate of passage but possibly to differences in the rate of digestion in the reticulo-rumen. The study of the rate of digestion has been attempted by using as a reference substance something that is wholly undigested. Chromium sesquioxide was unsatisfactory because of its irregular rate of passage, and the lignin ratio method had to be discounted when it was suspected that lignin is digested quite appreciably. This is now the subject of further study.

It has been found that cows receiving most water in relation to dry matter effect the greatest digestion of fibre on a hay diet, and the water content of material in the reticulo-rumen does seem to affect the digestibility of fibre. The digestion of protein and of fat, the role of micro-organisms in nutrition, and the synthesis of vitamins in the animal are among other nutritional studies.

There is a good deal of work on the physiology of the mammary gland and of milking, and on the influence of hormones in lactation. In work on milk secretion it has been found that mammary gland slices from non-ruminants use acetate very quickly and with a low respiratory quotient-indicating no appreciable fatty-acid formation. Other workers, however, have shown that large amounts of carbon from acetate pass into fat in the mammary gland of the rabbit. This discrepancy between experiments in vitro and in vivo seems to have been solved by adding glucose in the experiment in vitro (it would be present in the gland in vivo) when acetate is used with $\mathbf{a}$ high respiratory quotient.

Developments of earlier work involving thyroidactive iodinated casein have been made easier by the fact that the hormone $I$-thyroxine has beeome avail. able in a pure state at a reasonable cost. Yield increases up to half a gallon a day per cow have been found, and the effect on the composition of the milk is being studied.

Several investigations concern machine milking: The rate of milking is very variable, and the maximum number of $\mathrm{lb}$. in one minute during milking varies among most cnws between 4.0 and 11.5 , although figures for a few cows lie well outside each end of this range. The absorption of fat by teat cup liners is much reduced when the liners are well brushed in hot detergent, and the use of boiling caustic soda for removing fat from liners is being investigated.

There is a lot of work being done on the bacteriological quality of milk and milk products. This includes, in addition to the continuation of work on mastitis, the examination of flora before and after keeping-quality tests, the effect of penicillin on the bacterial content of milk and various bacteriological problems of butter and cheese. An extensive 